http://dx.doi.org/10.1590/0370-44672018720184

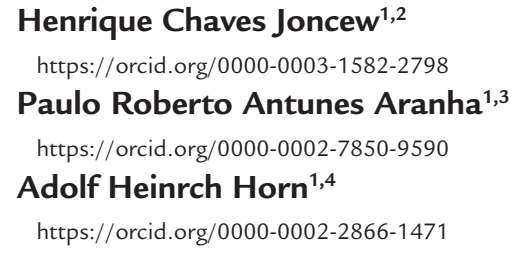

E-mails: ${ }^{2}$ henriquecj.geologia@gmail.com, 3aranha1941@gmail.com, ${ }^{4}$ hahorn@ufmg.br

\title{
Geoscięnces
}

\section{Structural and mineralochemical characterization of a pegmatite deposit in the Santa Rosa Pegmatite Field, Minas Gerais Brazil}

\begin{abstract}
The Santa Rosa Pegmatite Field (SRPF), in northeastern Minas Gerais State, is one of the most important gemstone sources in Brazil. The economy of several neighboring cities greatly relies on the trade of its gemstones. However, efforts to improve gemstone mining with practical, scientific methods are scarce, making it a yet inexpensive, marginally profitable practice. In this scenario, it is opportune to encourage new approaches to optimize mining in pegmatitic deposits. This study looked into the case of a tourmaline dig in the city of Franciscópolis, near Teófilo Otoni. The pegmatite has a weakly zoned structure, and was formed during the final stages of the Neoproterozoic Araçuaí Orogeny, associated with the intrusion and crystallization of the Santa Rosa Granite. GPR profiles were executed to locate structural anomalies inside the rock and its contacts with the host rock, and mineral samples were characterized based on compositional data obtained from ICP-MS and microprobe analyses. The results provided useful information that enabled the creation of a tridimensional digital model of the dig and the pegmatite dike, and may guide future operations in the dig. In the future, the proposed methodology may be applied to more cases to generate a database of geological information that, in addition to the economic scope, could lead to a better understanding of the local granite-pegmatite systems.
\end{abstract}

Keywords: Pegmatite, prospecting, GPR, geochemistry, modeling.

however, are startlingly rudimentary, in sheer contrast with their relevance in the local economy. Workers excavate without any orientation or technical support after gem pockets, which represent a diminutive part of the pegmatite structure and are randomly scattered throughout the rock. Geological mapping, compositional characterization and geophysical survey remain a distant reality, for lack of awareness, interest or information, even of dig owners who could afford such procedures. Long periods may pass between the discovery of gems, and incomes usually cover the expenses of previous fruitless efforts, making the ventures marginally profitable.

This study proposes a strategic approach for active underground gemstone digs in the SRPF using the present network of tunnels cutting pegmatite bodies. Taking the example of a dig near Franciscópolis-MG (Figure 1), this methodology increases knowledge on a tourmaline-hosting pegmatite and, with further research, may potentially assist mining in the future. A digital model was created from GPR profiles and compositional data were used to characterize mineralogical aspects of the rock.

The conditions found in the digs, 


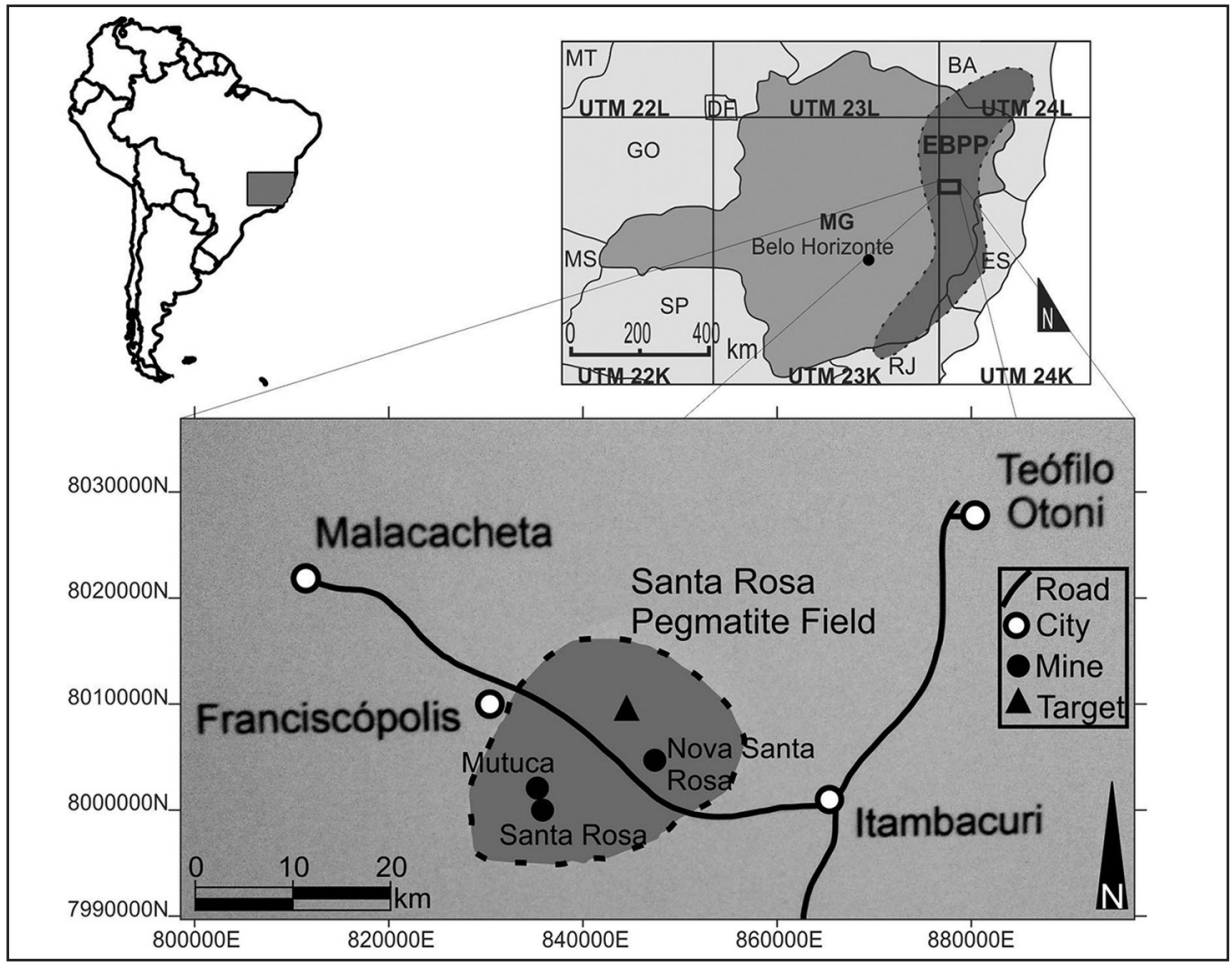

\section{Geological context}

The SRPF was formed in the Neoproterozoic period, during the crystallization of the Santa Rosa Granite, a late-collisional suite of the crystalline core of the Araçuai Orogen (Bayer et al., 1985, 1987; Paes, 1997; Pedrosa-Soares and WiedemannLeonardos, 2000; Pedrosa-Soares et al., 2001; Oliveira, 2016). The granite intruded the São Tomé and Tumiritinga Formations, composed of paraderived biotite schists and gneisses, deposited in a shallow marine environment in back-arc and fore-arc basins, respectively (Vieira, 2007). During the emplacement, contact metamorphism led to schist tourmalinization (Figure 2a) and the formation of tourmalinites of the Boronrich marine units (Oliveira, 2016). Finally, late-stage fluids differentiated from the melt and crystallized as pegmatites. The exsolution of fluxing components collaborated to the formation of pockets where gemstones could develop more easily (London, 1986, 1987, 2005; Simmons et al., 2012).

The pegmatite studied in this research is lodged in a biotite schist of the São Tomé Formation (Figure 2b). Dipping attitudes measured in the surface and in the tunnels showed a $70^{\circ}$ dip towards the NW quadrant, which is concordant to the schistosity. Subordinate dikes and apophyses occur in the vicinities of the main body. The pegmatite structure is weakly zoned, often marked by tourmaline crystals or agglomerates growing from the border to the center of a zone (Figure 2c). Decimetrical quartz crystals occur in the innermost zones, forming a discontinuous core. The main mineralogy of the pegmatite is composed by quartz, alkali-feldspars, tourmaline and garnet group minerals. Apatite and zircon

Figure 1

Location of the studied dig and the most important mines nearby in the Santa Rosa Pegmatite Field (Horn et al., 2018, modified from Cornejo et al., 2014).

are also present as accessories or inclusions.

The gemological tourmalines from the dig are blue or green (Figure 2d), and are found in pockets. However, most cavities are barren, filled with water, clay and, sometimes, black tourmalines without market value. Pockets have relatively round or oval shapes, reaching at most decimetric dimensions. A distinctive feature found in the frames are star-shaped muscovite crystals (Figure 2e).

Mining is developed underground, counting solely with the aid of explosives. However, there is no kind of guidance, so workers excavate randomly until finally finding mineralized pockets, which may take months or years. As a result, income from the sale of gems usually is destined mainly to cover the previous frustrated efforts.
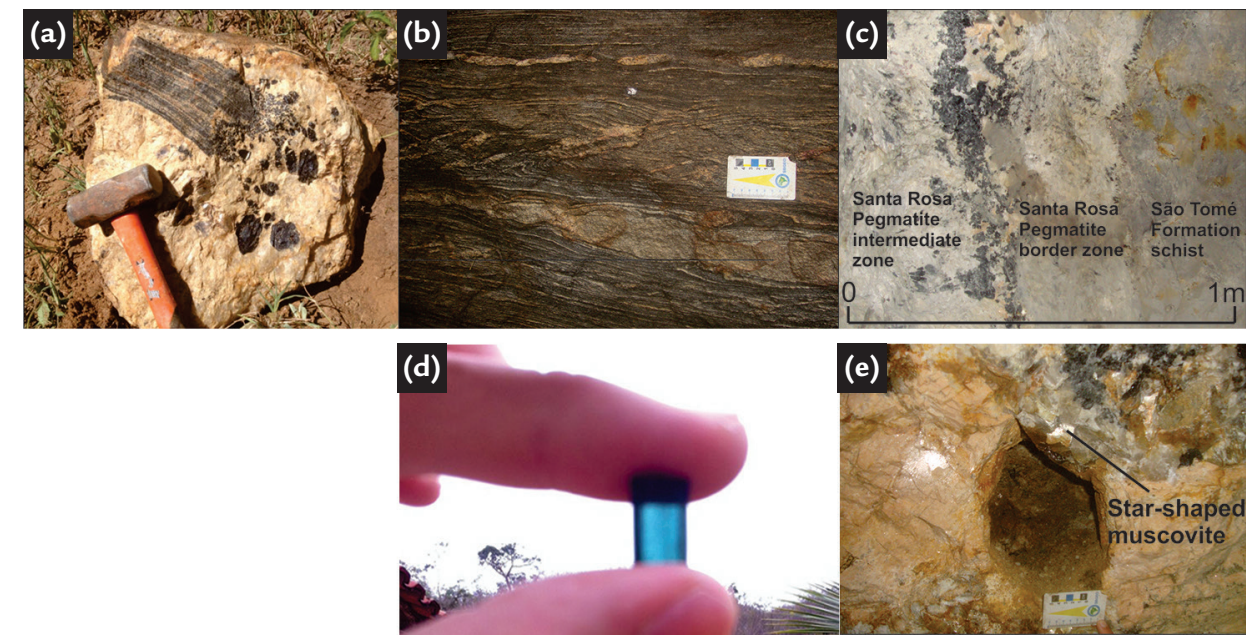

Figure 2

a) Santa Rosa Granite

with a tourmalinized schist xenolith

(Oliveira, 2016); b) Schist from the São

Tomé Formation, host rock to the pegmatite dike; c) Contact between the São Tomé schist and the Santa Rosa Pegmatite, with its zoned structure and crystal growth from the borders of each zone to the center; d) Small sample of blue gemological tourmaline from the studied dig; e) Star-shaped muscovite framing pocket. 


\section{Methods}

\subsection{Analytical methods}

\subsubsection{Sampling and preparation}

Samples were taken from the underground galleries, in different zones of the pegmatite (Figure 3), including points surrounding representative pockets with both gemological and non-gemological tourmalines, and a

Figure 3

Location of the sampling points and GPR profiles in the underground galleries in plant view (a), with the relative position of the sampling points in the pegmatite in plant view (b) and cross-section (c). Sampling point 1 was a reject pile outside the dig. barren, clay-filled vug. Tourmaline, feldspar and garnet were then manually separated from each of the rock samples. Next, with the aid of an agate ball mill, individual sets of these minerals were powdered for ICP-MS analyses, producing a total of 41 powder sets: 16 composed of tourmaline, 16 of feldspar and 9 of garnet. Finally, 23 polished thin sections were prepared for electron microprobe analyses: 14 made of tourmaline and 9 of garnet. (Table 1 ).

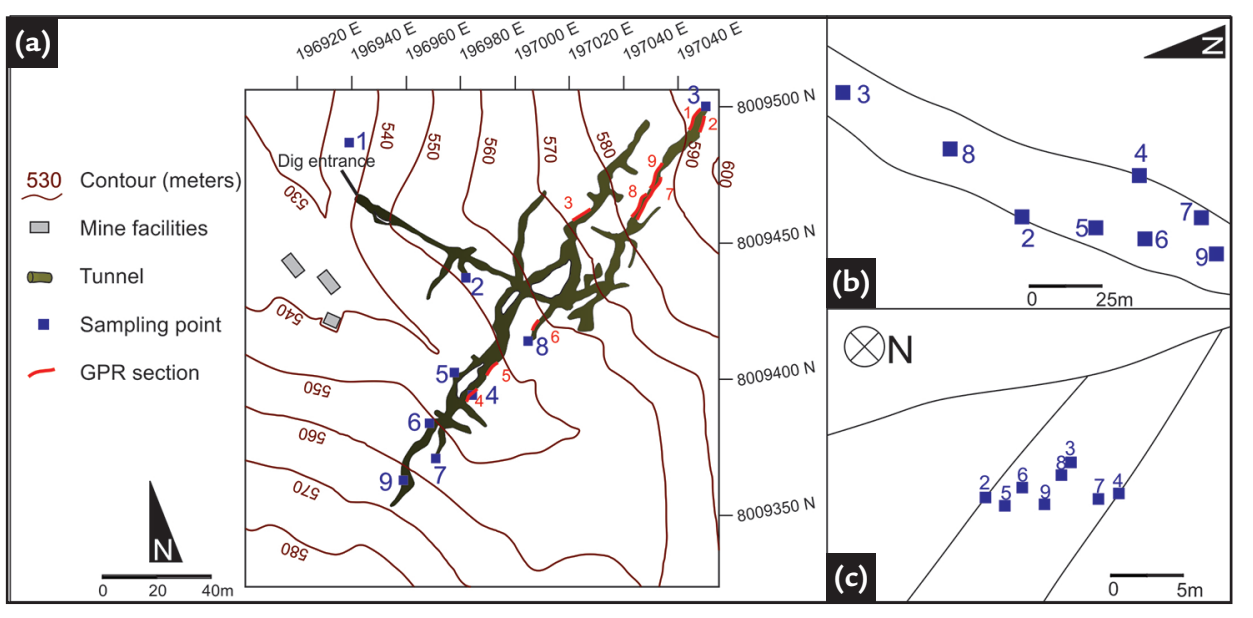

Table 1

Sample context in the Santa Rosa Pegmatite and mineral set preparation for chemical analyses.

\begin{tabular}{|c|c|c|c|c|c|c|c|}
\hline \multirow{2}{*}{ Point } & \multirow{2}{*}{ Sample } & \multirow{2}{*}{ Context } & \multicolumn{3}{|c|}{ Mineral set } & \multirow{2}{*}{ Polished sections for EMPA } & \multirow{2}{*}{ Pulverization for ICP-MS } \\
\hline & & & Tour & Garn & Feld & & \\
\hline \multirow{2}{*}{1} & $1 \mathrm{~A}$ & \multirow{2}{*}{ Reject pile } & $x$ & $x$ & $x$ & Tourmaline, garnet & Tourmaline, garnet, feldspar \\
\hline & $1 \mathrm{~B}$ & & $x$ & $x$ & $x$ & Tourmaline, garnet & Tourmaline, garnet, feldspar \\
\hline \multirow{2}{*}{2} & $2 \mathrm{~A}$ & \multirow{2}{*}{ Upper contact } & $x$ & & & Tourmaline & Tourmaline \\
\hline & $2 \mathrm{~B}$ & & & & $x$ & - & Feldspar \\
\hline 3 & 3 & Pegmatite, near quartz core & $x$ & & & - & Tourmaline \\
\hline 4 & 4 & Base contact & $x$ & $x$ & $x$ & Tourmaline, garnet & Tourmaline, garnet, feldspar \\
\hline \multirow{2}{*}{5} & $5 \mathrm{~A}$ & \multirow{2}{*}{$\begin{array}{l}\text { Tourmaline-bearing pocket } \\
\text { (non-gemological) }\end{array}$} & $x$ & $x$ & $x$ & Tourmaline, garnet & Tourmaline, garnet, feldspar \\
\hline & $5 B$ & & & $x$ & $x$ & Garnet & Garnet, feldspar \\
\hline \multirow{5}{*}{6} & $6 \mathrm{~A}$ & \multirow{5}{*}{$\begin{array}{l}\text { Tourmaline-bearing pocket } \\
\text { (gemological) }\end{array}$} & $x$ & & $x$ & Tourmaline & Tourmaline, feldspar \\
\hline & $6 \mathrm{~B}$ & & & & $x$ & - & Feldspar \\
\hline & $6 \mathrm{C}$ & & $x$ & & $x$ & Tourmaline & Tourmaline, feldspar \\
\hline & $6 \mathrm{D}$ & & & & $x$ & - & Feldspar \\
\hline & $6 \mathrm{E}$ & & $x$ & $x$ & $x$ & Tourmaline, garnet & Tourmaline, garnet, feldspar \\
\hline \multirow{6}{*}{7} & $7 \mathrm{~A}$ & \multirow{3}{*}{ Vug near base contact } & $x$ & & $x$ & Tourmaline & Tourmaline, feldspar \\
\hline & $7 B$ & & $x$ & & $x$ & Tourmaline & Tourmaline, feldspar \\
\hline & 7C & & $x$ & $x$ & $x$ & Tourmaline, garnet & Tourmaline, garnet, feldspar \\
\hline & 7D & São Tomé Fm. schist & $x$ & & & Tourmaline & - \\
\hline & $7 E$ & \multirow{2}{*}{$\begin{array}{l}\text { Non-tourmaline-bearing } \\
\text { pocket near base contact }\end{array}$} & $x$ & $x$ & $x$ & Tourmaline, garnet & Tourmaline, garnet, feldspar \\
\hline & $7 F$ & & $x$ & $x$ & $x$ & Tourmaline, garnet & Tourmaline, garnet, feldspar \\
\hline 8 & 8 & \multirow{2}{*}{ Pegmatite, near quartz core } & $x$ & & & - & Tourmaline \\
\hline 9 & 9 & & $x$ & & & - & Tourmaline \\
\hline
\end{tabular}

\subsubsection{Chemical analyses}

The powdered samples were sent to the laboratories of SGS Geosol Ltda.,
Vespasiano, MG, for ICP-MS analyses. Lithium metaborate was used to aid the sample dissolution in the flux and element standards were supplied by Merck (Darm- 
stadt, Germany).

Electron microprobe analyses (EMPA) were conducted in the Center of Microscopy at the Federal University of Minas Gerais, Belo Horizonte, MG, by cross-sections in several mineral grains to provide data about internal zoning and chemical variations. The equipment used was a JXA-8900RL probe. Readings were conducted under $15 \mathrm{kV}$ voltage and 20nA current, with counting time of 15s ( $\mathrm{Si}, \mathrm{Na}, \mathrm{Ti}, \mathrm{P}, \mathrm{F}, \mathrm{K}, \mathrm{Mg}, \mathrm{Ca}$ and $\mathrm{Fe}$ ) and 30s (Al, Cr, Mn). Mineral standards from NIST (Gaithersburg, MD, USA) were used as reference.

Mineral structural formulae were calculated with spreadsheets developed by Tindle (2002) and Tindle et al. (2002) and Brady and Perkins (2016). For tourmalines, approximations proposed by Burns et al. (1994) and Clark (2007) were used and Henry and Guidotti (1985) and Henry et al. (2011) were referred to for classification.

the values must sum to a constant $(100 \%)$. This problem was solved by using the centered logratio transform (Aitchison, 1982), which converts the values into a new, unconstrained set of data.

readings with a total station. Starting from the entrance, where the geographic coordinates were known with a GPS device, the station was moved underground, and oriented by reference checkpoints. The points were extracted on the software Data Geosys.

\subsubsection{Background on pegmatite-hosted gemstone prospecting}

The pioneering studies employing GPR in the study of pegmatites were Patterson (1996), Cook (1997) and Patterson and Cook (1999). Independently, Patterson (1996) used GPR to map aplitic pegmatite

\subsubsection{Application}

In this study, nine GPR profiles (locations in Figure 3a) were executed on the underground walls of the dig, using 100 and $200 \mathrm{MHz}$ antennae in a common offset setting. Despite not

\subsubsection{Processing}

Data processing was performed on the Interpex Gradix software, applying the following steps:

a. Declipping;

b. Dewow;

\subsubsection{Digital modeling}

Information on the morphology and the contacts between the Santa Rosa Pegmatite and the São Tomé schist on the surface

\section{Results}

\subsection{Mineral characterization \\ 4.1.1 Feldspars}

Feldspars are mostly white or tan, and occasionally pink. Closer to the surface, due to weathering, yellowish shades and

\subsubsection{Tourmalines}

Tourmalines are dark-colored, with shades of gray, brown, green, blue and black. Discrete magnetism is also observed. Intergrowth with feldspar and/or quartz is

dikes in the Little Three Mine, California, while Cook (1997) listed this method as a promising tool for gemstone prospecting in pegmatites. Together, these authors proved GPR to be successful at locating pockets in

being able to differ mineralized pockets from barren ones like $1 \mathrm{GHz}$, these frequencies are still capable of detecting anomalies - planar or punctual - within the pegmatite structure while also hav-

\author{
c. Time zero setting; \\ d. Window traces; \\ e. Background removal; \\ f. Gaussian filtering - 100 and \\ $200 \mathrm{MHz}$
}

are available on a private map elaborated during previous basic surveys, available in the mine support facilities. On the Micro- the Himalaya Mine, California, verifying even that high frequency $(1 \mathrm{GHz})$ antennae are capable of distinguishing between mineralized and non-mineralized pockets (Patterson and Cook, 1999).

ing a much greater power of penetration (10-20m versus less than $1 \mathrm{~m})$, enough to reach the edges of the rock, necessary for constructing a geologic model of the area.

mine 2016 software, topographic, geologic and geophysical data were combined to create a 3-D model of the pegmatite and the dig. g. Topographic correction;

h. Depth conversion - wave travel velocity: $110 \mathrm{~m} / \mathrm{ns}$. kaolinization are observed. Graphic texture is often present in intermediate zones of the pegmatite, where crystals reach up to decimetric dimensions. Samples belong to the series defined by the microcline-albite (K-Na) edge of the K-Na-Ca classification. often present. Millimetric sulfide and mica crystals are scarcely observed as inclusions. Specimens were classified as Li-poor-rock schorls (Henry and Guidotti, 1985) and belong to the alkali and X-vacant groups (Henry et al., 2011). Element distribution in tourmalines vary throughout the mine, but no pattern is observed. 


\subsubsection{Garnets}

Garnets are red or brown in color and, like tourmalines, are slightly magnetic. Small quartz or zircon crystals

\subsection{Element distribution}

Throughout the dig, peculiarities are observed in the compositions of tourmaline and feldspar samples. In tourmalines, $\mathrm{Al}$ contents decrease from the border zones of the pegmatite to the core, maintaining an approximately constant level in the intermediate zones. Fe and Mn percentages are also highest in the borders and roughly constant in the rest of the rock. However, near the gem-bearing pocket, these elements reach their lowest values (Figure 4a).

Nearly all elements are evenly distributed in feldspars. Yet, samples from the barren vug stand out from this trend, as Dy, Gd, Pr, Hf, Nb and Ta contents fall below detection limits,

Figure 4

Significant element content variations in minerals from different zones of the Santa Rosa Pegmatite. a) $\mathrm{Al}_{2} \mathrm{O}_{3}, \mathrm{Fe}_{2} \mathrm{O}_{3}$ and $\mathrm{MnO}$ distribution in tourmaline samples; b) $\cup, \mathrm{Gd}, \mathrm{Dy}, \mathrm{Pr}$, $\mathrm{Nb}, \mathrm{Ta}$ and $\mathrm{Hf}$ distribution in feldspars. are frequent as inclusions. Samples are Mn-rich, which is expected in pegmatites (Manning, 1983). Chemical compositions

while $U$ percentages are much higher than average (Figure 4b). Furthermore, high $\mathrm{K}$ specimens occur solely near mineralized pockets.

As for internal compositions, fluctuations in element percentages inside mineral grains are common, but discrete. That is true even for samples from the vicinities of pockets - which are affected by late-stage substitution processes. Nevertheless, some distinguishing features are observed between minerals from various sampling points. Figure 5 represents the most important internal variations in mineral compositions. In tourmaline grains from the contact zones of the pegmatite, the Fe content form an intermediate range between almandine and spessartine $\left(\mathrm{Alm}_{58-76 \%}\right.$, Spss $_{21-40 \%}$ ).

has a constant distribution in the former, while showing a more erratic behavior in the latter. Some garnets - including all samples from the gem-bearing pockets are zoned, with an increase in Si and Al from the core to the rims, accompanied by Mn decrease.

Minerals from the pocket zones also have traits that may be used for comparison. Tourmaline grains from the gem pocket and the barren, clay-filled cavity are characterized by $\mathrm{Al}>\mathrm{Si}$. Also, some of these samples have lower Fe content than those from the other pockets. Tourmalines from the non-gemological pocket show similar $\mathrm{Al}$ and $\mathrm{Si}$ quantities and high Fe percentages.

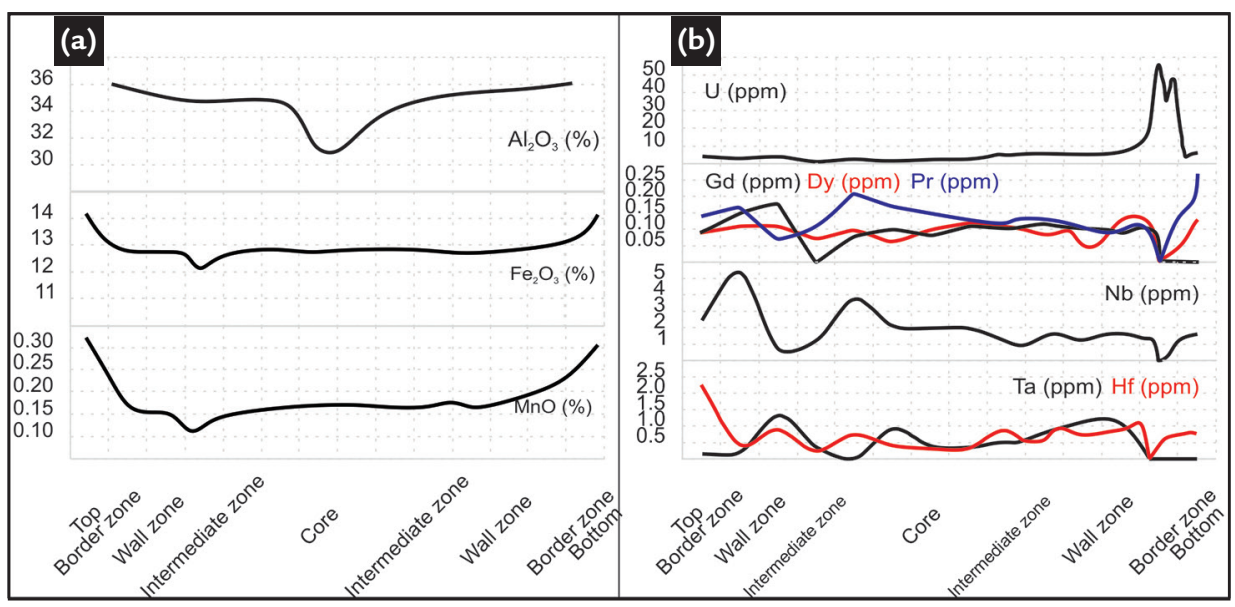

Figure 5

Representative schemes synthetizing the internal distribution patterns of selected elements in tourmaline (41) and garnet (28) grains from the Santa Rosa Pegmatite, obtained from EMPA profiles.
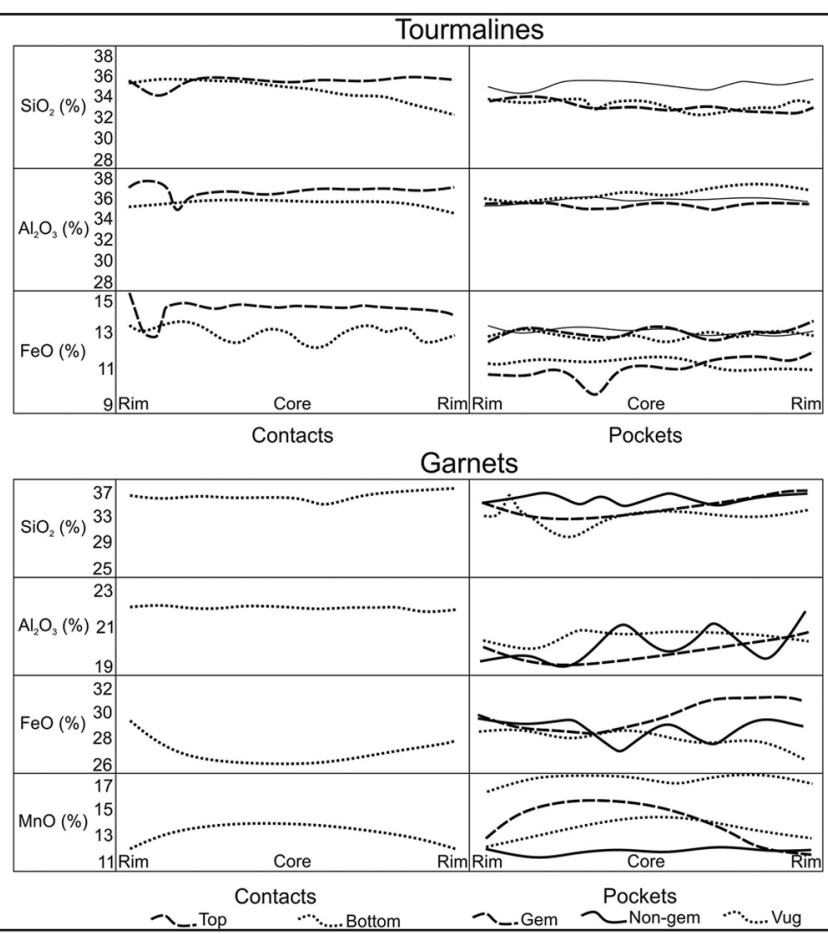


\subsection{Principal components analysis}

The PCA method showed no particular distribution that distinguished tourmaline (Figure 6a) and garnet samples from mineralized and nonmineralized zones. For feldspars, how-

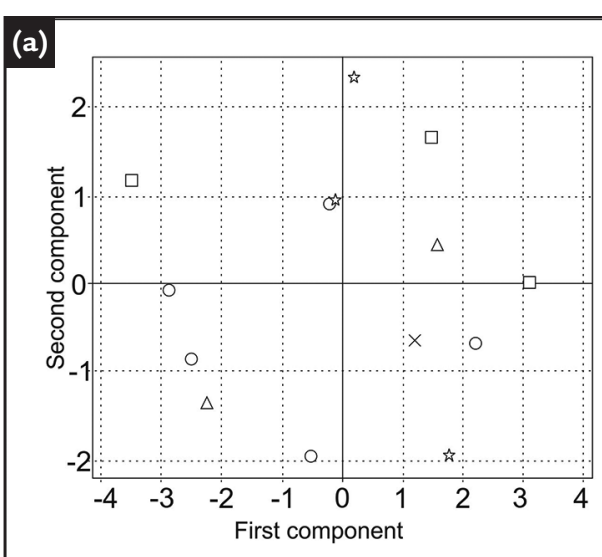

ever, an important feature is observed. When the analysis is applied to major element composition, samples from gem-producing pockets fall into two isolated groups from the rest (Figure

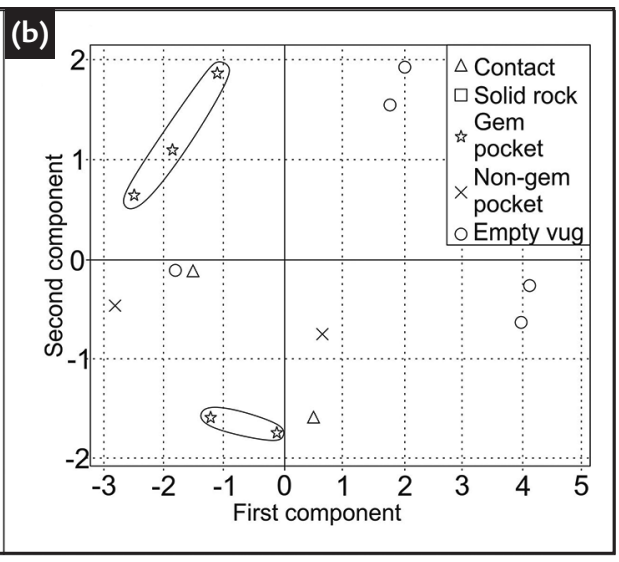

\subsection{Modeling}

\subsubsection{GPR sections}

The GPR profiles were successful at finding the edges and anomalies in the pegmatitic body. Reflection patterns in the dike are marked by series of strong, parallel lines (S), broken only by hyperbolic features

(A) or signal discontinuities (D). A change of pattern into a weaker, diffuse signal occurs on the pegmatite-schist contact, due to the contrast of wave impedance on the interface. The position of the contact surfaces 6b). Both groups have negative score values for the first component and high module values for the second (positive for K-feldspars and negative for $\mathrm{Na}$-feldspars).
Figure 6

Score plot diagrams generated by PCA analyses of major element compositional data of tourmaline (a) and feldspar (b) samples.

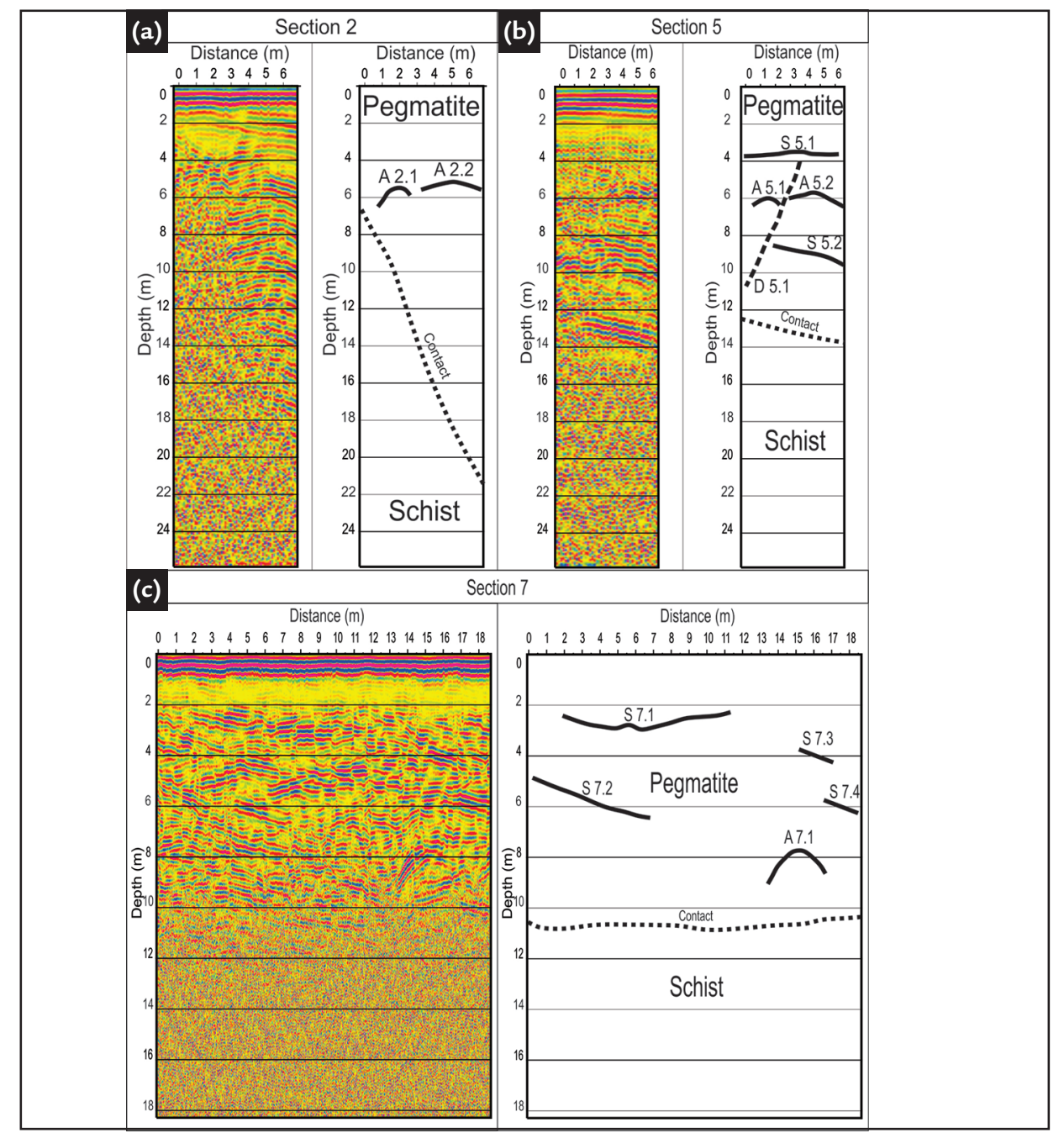

on the profile depends on the position of the tunnel section in relation to the strike of the pegmatite dike. Figure 7 shows examples of radargrams acquired on the walls of the tunnels, and their respective interpretations.

Figure 7

Examples of radargrams acquired after the execution of the GPR sections on the walls of the tunnels of the Santa Rosa Pegmatite and their respective interpretations. a) Section 2; b) Section 5; c) Section 7. 


\subsubsection{Digital model}

Figure 3 a shows the plant view of the tunnels and the locations of the GPR sections, registered during the topographic survey. The geophysical

Figure 8

a) Geological block diagram of the study area; b) Block diagram of the main pegmatite dike, containing the galleries inside.

\section{Discussion}

Distinguishing features are present near pocket zones. Feldspars from these vicinities stand out from the others in statistical distribution, and high $\mathrm{K}$ minerals are restricted to mineralized zones. Moreover, $\mathrm{Al}>\mathrm{Si}$ and low Fe and Mn contents in tourmalines and $\mathrm{Fe}$ and $\mathrm{Mn}$ zonation in garnets also indicate gem-bearing pockets. Combining this information with GPR readings may importantly assist the search for gems in the dig, since not only does it direct excavations towards punctual anomalies, but also allows the evaluation of the potential for success of the effort beforehand.

Regarding the statistical analyses, it was not the scope of this study to determine correspondences between the

\section{Conclusion}

The analyses conducted in this study were capable of identifying structural and chemical characteristics of the Santa Rosa Pegmatite and its minerals that are interesting for the expansion and optimization of the activities in the dig. ICP-MS and PCA analyses of tourmalines and feldspars produced results that establish whether or not a mineral was formed near a mineralized pocket. The contacts found in the GPR sections are coherent with the pegmatite dipping attitude in the surface, and the resulting tridimensional model is coherent with the distribution of the galleries. data allowed the creation of a block diagram for the local geology (Figure $8 \mathrm{a})$. The resulting model for the main pegmatite was an $8 \mathrm{~m}$-thick, sheetlike

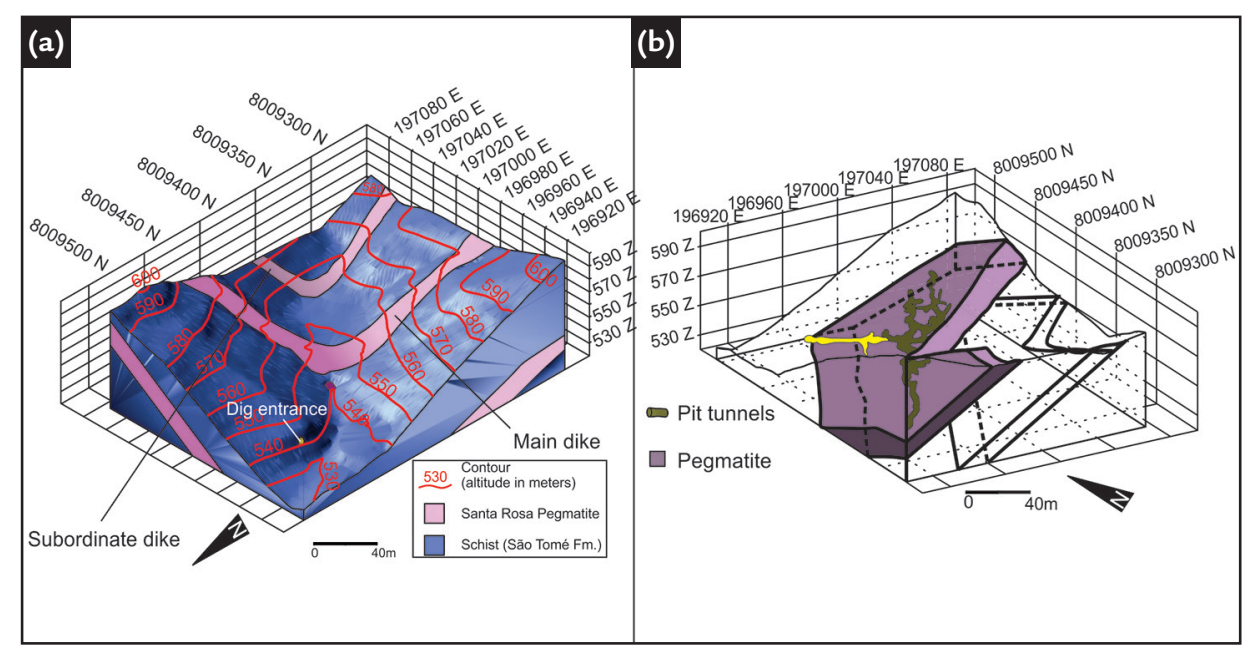

components and physical factors that could drive mineralochemical variations in the pegmatite during crystallization, although studies regarding that matter might be performed in the future by Factor Analysis, a more thorough statistical method.

The GPR sections provided geological contacts that resulted in a model for the pegmatite dike, coherent with the attitudes measured in the surface and in the galleries, as well as the distribution of tunnels dug in the rock. Plus, the anomalies found may fit two categories: surfaces $(S, D)$, which may be caused by planar structures, such as fractures, and points (A), which may correspond to xenoliths, vugs or pockets. Even though it is not possible

With better understanding of the pegmatite, prospective methods may be deployed to identify potential zones of interest. The approach used in this study does not ascertain whether the targets will be fruitful. However, more precise methods such as that of Patterson and Cook (1999) have a more limited range of action (high GPR frequencies reach less than $1 \mathrm{~m}$ inside the pegmatite), which is not compatible with the metric dimensions of the pegmatite dikes of the Santa Rosa Pegmatite Field. Moreover, the application cost of the studies is accessible for dike, dipping approximately $70^{\circ}$ towards NW, which fits the distribution of galleries observed and registered during the study (Figure 8b). to establish the nature of punctual anomalies, they constitute a primary object of interest for excavations.

This methodology may be expanded to deeper, more robust and extensive studies regarding not only gemstone prospecting, but also the geologic evolution of the Santa Rosa Pegmatite Field and its relationship to the surrounding granitic intrusions. Even though this study employed a basic approach, principal components analysis, if performed to a larger extent, is a powerful statistical method that may assist in the identification of various factors that controlled crystallization, which may provide important insights regarding how the SRPF was formed. the local enterprises, making them appropriate for the current activities and brownfield research in the numerous underground digs in the region.

The methodological approach presented herein thus provides a scientific support that gemstone digs in the Santa Rosa Pegmatite Field lack. Mining in the region is currently a random practice, and knowing the physical and chemical peculiarities of the pegmatites is the first step to create parameters for prospective methods that, in the future, may make the process more efficient and profitable. 


\section{Acknowledgments}

Proper thanks are due to UFMG, Mine Invest Brazil Ltda. and Mr. Jean Claude Nydegger for the logistical support, to the Center of Microscopy at UFMG for the technical support and chemical analyses and to $\mathrm{CNPq}$ (grant 481382/2012-7) for funding this research.

\section{References}

AITCHISON, J. The statistical analysis of compositional data. Journal of the Royal Statistical Society, v. 44, p. 139-177, 1982.

BAYER, P., HORN, A. H., SCHMIDT-THOMÉ, R., LAMMERER, B., WIEDEMANN, C. M., WEBER-DIEFENBACH, K. The Braziliano Mobile Belt in southern Espírito Santo (Brazil) and its igneous intrusions. Zentralblatt für Geologie und Paläontologie, v. 9, p. 1429-1439, 1985.

BAYER, P., SCHMIDT-THOMÉ, R., WEBER-DIEFENBACH, K., HORN, A. H. Complex concentric granitoid intrusions in the Coastal Mobile Belt, Espírito Santo, Brazil: the Santa Angélica Pluton. Geologische Rundschau, v. 76, p. 357-361, 1987.

BRADY, J., PERKINS, D. Mineral formulae recalculation, 2016. Available at https://serc.carleton.edu/research_education/equilibria/mineralformulaerecalculation.html. Accessed 20 April 2016.

BURNS, P. C., MACDONALD, D. J., HAWTHORNE, F. C. The crystal chemistry of manganese-bearing elbaite. Canadian Mineralogist, v. 32, p. 31-41, 1994.

CLARK, C. Tourmaline: structural formula calculations. Canadian Mineralogist, v. 45, p. 229-237, 2007.

COOK, F. A. Application of geophysics in gemstone exploration. Gems \& Gemology, v. 33, p. 4-23, 1996.

CORNEJO, C., BARTORELLI, A., MENEZES-FILHO, L. A. D. A subclasse dos ciclossilicatos. In: CORNEJO, C., BARTORELLI, A. (Eds.). Minerais e pedras preciosas do Brasil. São Paulo: Solaris, 2014. cap. 11, p. 444-593. 712 p.

DAVIS, J. L., ANNAN, A. P. Ground penetrating radar for high resolution mapping of soil and rock stratigraphy. Geophysical Prospecting, v. 37, p. 531-551, 1989.

EVERETT, M. E. Near-surface applied Geophysics. New York: Cambridge University Press, 2013. 441p.

HENRY, D. J., GUIDOTTI, C. V. Tourmaline as a petrogenetic indicator mineral: an example from the staurolite-grade metapelites of NW Maine. American Mineralogist, v. 70, p. 1-15, 1985.

HENRY, D. J., NOVÁK, M., HAWTHORNE, F. C., ERTL, A., DUTROW, B. L., UHER, P., PEZZOTTA, F. Nomenclature of the tourmaline supergroup minerals. American Mineralogist, v. 96, p. 895-913, 2011.

HOLANDA, S. B. Monções e capítulos de expansão paulista. São Paulo: Companhia das Letras, 2014. 624p.

HORN, A. H., ARANHA, P. R. A., JONCEW, H. C. Combined mineralochemical, statistical and geophysical data as support for the exploration of pegmatite-hosted gemstones: example from the Santa Rosa Mine, MG, Brazil. Romanian Journal of Mineral Deposits, v. 91, n. 1-2, p. 1-6, 2018.

LONDON, D. Formation of tourmaline-rich gem pockets in miarolitic pegmatites. American Mineralogist, v. 71, p. 396-405, 1986.

LONDON, D. Internal differentiation of rare-element pegmatites: Effects of boron, phosphorus, and fluorine. Geochimica et Cosmochimica Acta, v. 51, p. 403-420, 1987.

LONDON, D. Granitic pegmatites: an assessment of current concepts and directions for the future. Lithos, v. 80, p. 281-303, 2005.

MANNING, D. A. C. Chemical variation in garnets from aplites and pegmatites, peninsular Thailand - a correction. Mineralogical Magazine, v. 47, p. 353-358, 1983.

NETTO, C., ARAÚJO, M. C., PINTO, C. P., DRUMMOND, J. B. V. Projeto Leste - cadastramento de recursos minerais. Belo Horizonte: SEME/COMIG/CPRM, 1998. 197p.

OLIVEIRA, B. N. Mapeamento geológico da área entre Itambacuri-Franciscópolis, microregião de Teófilo Otoni - MG. Belo Horizonte: UFMG, 2016. 108p. (Gra- 
duation monograph).

PAES, V. J. C. Projeto Leste - Folha Teófilo Otoni-SE.24-V-C-IV, escala 1:100.000. Belo Horizonte: COMIG/CPRM, 1997. 39p.

PAIVA, G. Províncias pegmatíticas do Brasil. Rio de Janeiro: DNPM/DFPM, 1946. p. 13-21 (Bulletin 78).

PATTERSON, J. E. Modeling of layered aplitic pegmatite dikes using ground penetrating radar, Little Three Mine, Ramona District, San Diego County, California. Tucson: University of Arizona, 1996. Unpaged. (The Spirit of Inquiry 17).

PATTERSON, J. E., COOK, F. A. Successful application of Ground Penetrating Radar in exploration for gem tourmaline. Canadian Mineralogist, v. 37, p. 862-863, 1999.

PEDROSA-SOARES, A. C., NOCE, C. M., WIEDEMANN, C. M., PINTO, C. P. The Araçuaí-West-Congo Orogen in Brazil: an overview of a confined orogen formed during Gondwanaland assembly. Precambrian Research, v. 110, p. 307-323, 2001.

PEDROSA-SOARES, A. C., WIEDEMANN-LEONARDOS, C. M. Evolution of the Araçuaí Belt and its connection to the Ribeira Belt, eastern Brazil. In: CORDANI, U. G. et alli (Eds.). Tectonic evolution of South America. Rio de Janeiro: Sociedade Brasileira de Geologia, 2000. cap. 3, p. 265-285. 854 p.

PUTZER, H. Metallogenetische Provinzen in Südamerika. Stuttgart: E. Schweitzerbart'sche Verlagbuschhandlung, 1976. 316p.

REIS, F. P. O imaginário metalista luso-brasileiro colonial: a Serra das Esmeraldas na segunda metade do século XVII. Cordis, v. 3-4, p. 1-12, 2010. Available at http://revistas.pucsp.br/cordis/article/view/9546. Accessed 07 January 2016.

SIMMONS, W. B., PEZZOTTA, F., SHIGLEY, J. E., BEURLEN, H. Granitic pegmatites as sources of colored gemstones. Elements, v. 8, p. 281-287, 2012.

TINDLE, A. G. Mineral formula calculation worksheets, 2002. Available at http:// www.open.ac.uk/earth-research/tindle. Accessed 20 April 2016.

TINDLE, A. G., BREAKS, F. W., SELWAY, J. B. Tourmaline in petalite-subtype granitic pegmatites: evidence of fractionation and contamination from the Pakeagama Lake and Separation Lake areas of northwestern Ontario, Canada. Canadian Mineralogist, v. 40, p. 753-788, 2002.

VIEIRA, V. S. Significado do Grupo Rio Doce no contexto do Orógeno Araçuaí. Belo Horizonte: UFMG, 2007. 117p. (Doctoral thesis).

Received: 9 December 2018 - Accepted: 2 March 2019. 